\title{
A estrutura psicorgânica do homem impotente
}

Maria das Graças Silva*

Falar de impotência é falar de todos nós seres humanos que no decorrer de nossas vidas e em tantos momentos somos impotentes, não conseguimos caminhar, sentimos o corpo pesado, cansado e a mente embutida. Portanto não conseguimos associar o que sentimos com o que pensamos em frente as nossas atitudes. Logo, ficamos inertes, impotentes...

Mas a impotência a qual me refiro é mais profunda, onde o vivenciar da vida cortou a raiz mãe, deixando as ramificações pulsando sua dor pelo corte da desestrutura de uma carência de vida.

Estou falando do homem impotente e de sua sexualidade, onde o pênis em frente às excitações sexuais não consegue obter resposta sensório-neuromuscular da ereção, pois a sua estrutura somática, visceral e endocrina na história de sua vivência ficou deformada, bloqueada no seu desenvolvimento sociopsicossexual ou do tubo sexual e social. É o espelho

\footnotetext{
* Psicoterapeuta do Instituto Kaplan, São Paulo. 
da desestrutura do nosso corpo, onde podemos detectar as couraças musculares ou debilidades neuromusculares nas posturas corporais e nas atitudes de vida desse homem consigo mesmo e com seu meio ambiente. A constatação de sua potência, era ansiedade e angústia, onde o pavor nos olhos e a tensão de endurecimento ou corpo cansado caído se faz presente. É uma situação sufocante que se projeta dentro de imagens internas como se fosse um filme em alta rotação, com imagens externas do momento vivido junto a uma autocobrança de um "pinto" ereto, que muitas vezes é transferido e cobrado acusando a sua parceira, com quem viveu ou está vivendo neste momento.

Enfim, a impotência de se sentir impotente como um homem viril faz com que ele transfira essa dor para seus, familiares, amigos e principalmente para o seu trabalho.

Há uma queda geral da energia que envolve este homem e o leva a não se sentir, não se perceber inteiro no seu dia-a-dia. Este ser fragmentado não se faz impotente de um dia para o outro, pois são as consequiências de sua história de vida, sofrida de carência do alimento afeto e do alimento-comida, e de toda uma história de dor, de luta para sobreviver neste mundo de valores, padrões, modelos criados pelos sistemas dominantes. Num dado momento este Ser homem não agüenta e rompe, e este rompimento é um arrombamento na sua força de vida que se situa na energia sexual, resultado final da sua impotência de vida.

Este é o momento de constatar, ele colocar os pés no chão, de entrar na realidade, em contato com a sua pobreza afetiva desde a mais tenra idade. com suas oscilações de angústia e ansiedade na busca da sua própria identidade na adolescência, para constatar o círculo vicioso da sua dicotorma afetivo-sexual na fase adulta. com isso um autoprovar no decorrer de sua vida.

Assim constatamos uma dor que penetra nas mais profundas camadas do nosso corpo, alma e espírito.

Acredito que desde o surgirnento do homem no mundo a impotência sexual se faz presente, pois é um problema no processo do amadurecimento do desenvolvimento psicossexual ou do tubo sexual, da relação da aceitação intra-uterina no processo simbiótico mãe e filho, da relação do contato do recém-nascido com o calor do toque (aconchego e o sugar do seio). da relação da sua maturação com a mãe, pai, familiares, estruturas sociais. valores morais e religiosos. Neste processo há o amadurecimento das fases em busca da sua identidade sexual, conseqüentemente social, de se sentir integrado consigo mesmo no seu eixo neuro-psico-corporal, onde os processos sensório-perceptivos se fazem 
presente, ou seja, um honem confiante, capaz de amar e produzir para si e para sua sociedade.

Afinal estamos quase chegando no século XXI, no aprimoramento da tecnolollia, no avanço das maquinas, dos computadores onde o homem se faz "Robô", e o Céu é o Limite.

Verificamos que a tecnologia avança em todos os setores, a portanto não podemos deixar de vivenciá-la. integrando-a ao homem impotente, que em busca do "pinto ereto", pois este desde que o mundo é mundo tem a força do poder, se entrega nas mãos de alguns profissionais que não se autopercebem como Ser Total e projetam nos seus pacientes a sua própria fragmentação, ou mesmo profissionais chamados "máquinas humanas", também fragmentados, que estão apenas em busca de status, com isso eles estão fazendo transferências das manipulações que sofreram e sofrem, e continuam a ser conduzidos pelos sistemas, apenas mudaram de mãos, se entregam confiantes como confiaram no útero materno, ao contato do calor humano no decorrer do seu desenvolvimento.

Hoje, há a moldagem da prótese peniana na sua forma, espessura, tamanho como se essa energia de vida fosse um pedaço de um objeto que pode ser manuseado ao bem querer.

O homem é o resultado da ciência, metafísica, psicologia, filosofia dentro do seu sistema social e cultural, é complexo e multidimensional; a solução não se encontra em usar uma única direção, mas é preciso refletir esta dificuldade em sua totalidade.

Portanto, é a combinação dos avanços tecnológicos com a constatação do problema psicorgânico, a impotência sexual, que pode obter resultados positivos e satisfatórios, desde que consigamos integrar esse homem Ser dentro deste homem Ter, para obter uma prótese peniana que propicie sua auto-satisfação e bem-estar.

Observei que os homem impotentes sexualmente, após prótese peniana e resultados satisfatórios clinicamente, não apresentaram necessariamente mudanças nas suas estruturas psicorgânicas e no seu modo de Vida. O "pinto" está ereto, mas a mente, o corpo e o espírito continuam os mesmos, a história é a mesma, logo eternos insatisfeitos e toda uma história de carências afetivas e alimentares. Na realidade, precisamos interá-los com eles mesmos, pois o processo anatômico é uma profunda e poderosa ciência produzida por imagens emocionais internas, as formas ele nossos corpos e órgãos internos nos falam da nossa mente e do nosso espírito. Isso ocorre, pois todo processo sensoperceptivo vem através dos receptores proprioceptivos, visceroceptivos e interoceptivos, os quais são as bases dos programas cerebrais conscientes e inconscientes que nos con- 
duzem a vivenciar o que sentimos, pensamos e agimos. Assim, verificamos que um dos elementos fundamentais encontrados nos seres vivos é a organização pulsátil, capaz de contrair e expandir, de aumentar e diminuir, amolecer e endurecer, de acordo com as nossas histórias de vida. O nosso tecido cerebral também pulsa, se contrai e se expande, para circulação do líquido cérebro-espinhal. Todo organismo é uma bomba pulsátil e o nosso sentimento e pensamento é baseado nessa ação bombeante.

portanto, são as nossas emoções conectadas as nossas memórias antigas e recentes, as duais possuem as mesmas bases neurais da amígdala, situada no lobo temporal pertencente ao sistema límbico, que concentram todas as informações sensoriais e exercem um papel de interface entre os estímulos do ambiente e o retomo das reações. O homem é um organismo autoproduzido.

A partir dessas formas somáticas, viscerais e endócrinas ficamos conhecendo a história genética, social e pessoal. A anatomia, a fisiologia, a cinesiologia e a neurologia emocional constituem-se de camadas de pele, músculos, órgãos e a camada invisível de hormônios ligadas à grande e pequena circulação, favorecendo ou desfavorecendo esse Ser homem.

Essas estruturas emocionais mostram as relações entre forma e as forças genéticas e sociais que inibem ou facilitam a formação de uma vida que contém mistérios ancestrais, desafios atuais e um gancho para o futuro.

\section{REFERÊNCIAS BIBLIOGRÁFICAS}

1. HEICH, W. (1978). Psicologia de Massas do Fascismo. São Paulo: Antídoto.

2. FROMM. E. (1972). Análise do Homem. Rio de Janeiro: Zahar.

3. VAYER. P. (1969). Equilíbrio Corporal. Rio de Janeiro: Editorial CientíficoMédica.

4. ERIKSON, E. H. (1976). Identidade, Juventude e Crise. Rio de Janeiro: Zahar.

5. MACHADO, A. (1981). Neuroanatomia Funcional. Rio de Janeiro: Ateneu.

6. GUYTON. A. C. (1984). Fisiologia Humana e Mecanismos das Doenças. Rio de Janeiro: Interamericana.

7. CAPRA. F. (1988). Sabedoria lncomum. São Paulo: Cultrix. 